\title{
CORRESPONDENCE
}

\section{Forestry Policy}

SiR,-Your petulant footnotes to Professor Wareing's letter (Nature, 241, $414 ; 1973)$ are no more convincing than the assertions in your editorial that he so clearly corrected. On forest research there is one further point that needs to be made. The service given to private forestry by the Forestry Commission's research programme, and by individual officers of the Research Division, is of immense value and has been a major factor in the achievement of the very high standard of management now existing in private woodlands. This Society would wish to see the Research Division strengthened rather than dismembered as you suggest.

It is not against the annual operating costs of the state forests that the forest research budget should be assessed, but against the total value of the productive woodlands of Great Britain, a figure in excess of $£ 1,000$ million; on such an assessment the modest $0.1 \%$ spent on research is surely inadequate.

In your review of Forestry Policy in general your unquestioning acceptance of the figures produced by the anonymous team of Government economists, and their theoretical basis, is worrying. Both have been shown to be unsound (Quart. J. Forestry, 66, No. 4) and further evidence is accumulating of much available information having been omitted, which, among other things, reverses the costs to the exchequer of jobs in state forestry and in agriculture stated in paragraph 19 of the Forestry Policy paper, which you quote. There are other gross errors of assumption, much unrealistic oversimplification, and much defective deduction in the study, which explains why most of it was discarded by ministers in the paper.

You make reference to the agricultural policy of the European Community. I draw your attention first to the Mansholt Plan for Agriculture in the EEC, wherein it is proposed that more than 4 million hectares of agricultural land shall be forested; secondly, to the draft EEC Directive on Forestry signed by the Council of Ministers on January 10, 1973, which details the measures by which this is to be brought about. These measures include: 70 to $90 \%$ subsidy for forestation of agricultural land; 50 to $70 \%$ subsidy for increasing the productivity of existing woods and forests; an additional annual grant, lasting for 5 to 12 years, for forestation of marginal agricultural land; cancellation of all subsidies for conversion of woodland to agriculture.

You make no mention of the future needs of this country for timber and wood products. Yet both the rate of consumption, and the cost, continue to rise. In its weak commercial position it is doubtful whether this country can afford the projected level of import, even if the material is physically and politically available, which is also doubtful. Europe is a net importer of wood; the nine EEC countries import $57 \%$ of their requirements. In these circumstances the continued expansion of the area of productive forest under sustained management in Great Britain is a prudent and sensible investment.

Your four-point plan for forestry reveals a distressing lack of first hand knowledge. Available literature, much of it free, and the Guide Map to Your Forests recently published by Bartholomew for the Forestry Commission which is on sale at booksellers, enable anyone to go and judge for themselves how imaginatively the recreational facilities of the forests are being developed. You will find too that the people who use them do so because of the trees, not in spite of them.

Your vision of the forests being exploited as recreational parks by private commercial organizations is a horrifying one. The attractions and advantages of a silvicultural setting for recreation are many and various; one of the main ones is that the management is in the hands of ecologically trained foresters who love their trees, the land on which they grow, the wealth of wildlife they support, and can interpret their understanding and transmit their enthusiasm to visitors. They are also able to obtain a remarkable degree of local involvement, support, cooperation, and goodwill in developing the cultural potential of their forests, which surely would not be forthcoming under the system you advocate.

Selective planting has been standard silvicultural practice for many years, as has the encouragement of colonization by native species of the land within the forest judged too poor to plant, and of other areas deliberately left unplanted for that purpose.

A $3 \%$ return in terms of timber, with the added social benefits of providing rural employment, amenity, shelter, water and wildlife conservation, recreation, sport, the framework of new landscapes and the perpetuation of existing ones, a primary source of energy, and a form of land use integrated with agriculture, makes forestry one of the best forms of investment for the nation. Yours faithfully,

P. F. GaRThWAITE

The Royal Forestry Society,

102 High Street,

Tring, Hertfordshire

\section{Good Intentions}

Sir,--It gives me no pleasure to criticize well-meaning colleagues for their good intentions regarding suffering mankind ("Vietnam Bombing," Nature, 241, 487 ; 1973), but in politics as in science good intentions alone are not enough.

The notion was advanced that appeals for international morality and the adoption of moral postures by neutralist politicians would do good. What evidence is there to support this hypothesis? During this century two world organizations were established precisely in order to solve the world's many problems in a moral way; let us not shrink from calculating the ratio of successes to failures. Let us also recall with painful nostalgia the politics of the 1930s; then, our kindly, democratic politicians and their well-meaning supporters pursued their moral policies until the political nemesis of 1939 ; then, distinguished neutralists including Roosevelt and Gandhi-and perhaps also a Scandinavian or two--scored full marks for pontification but zero for knowledge of, and interest in, the relevant power stakes; then, those who bothered to deduce the counterproductivity of such high-minded naivety were abused as warmongers and worse.

If Dr Morten Simonsen is convinced by his historical analyses that preaching is the most effective method for realizing political ends, let him enlighten and convince us-with his examples. But if, like Henry Ford, he dismisses history as bunk, let him not wonder how such men as Talleyrand, Bismarck, Disraeli, Marx, Lenin, and even Kissinger successfully advanced their policies. Can anyone believe that the political wilderness would be more amenable to the moralism of contemporary political babes than it was at the time of the Children's Crusade? Yours faithfully,

8 Suffolk Road, O. LL. LLOYD

Edinburgh 9 